\begin{tabular}{|l|l|l||}
\hline \multicolumn{2}{|c|}{ PublisherInfo } \\
\hline \hline PublisherName & $:$ & BioMed Central \\
\hline \hline PublisherLocation & $:$ & London \\
\hline \hline PublisherImprintName & $:$ & BioMed Central \\
\hline \hline
\end{tabular}

\title{
ZACdownregulation in breast tumors
}

\begin{tabular}{|l|l|l||}
\hline \multicolumn{2}{|c||}{ ArticleInfo } \\
\hline \hline ArticleID & $:$ & 3625 \\
\hline \hline ArticleDOI & $:$ & $10.1186 /$ bcr-1999-66603 \\
\hline \hline ArticleCitationID & $:$ & 66603 \\
\hline \hline ArticleSequenceNumber & $:$ & 45 \\
\hline \hline ArticleCategory & $:$ & Paper Report \\
\hline \hline ArticleFirstPage & $:$ & 1 \\
\hline \hline ArticleLastPage & $:$ & 4 \\
\hline \hline & & RegistrationDate : 1999-8-13 \\
\hline ArticleHistory & $:$ & OnlineDate \\
\hline \hline ArticleCopyright & $:$ & Current Science Ltd1999-8-13 \\
\hline \hline ArticleGrants & $:$ & \\
\hline \hline ArticleContext & $:$ & 1305811 \\
\hline \hline
\end{tabular}




\section{Keywords}

6q25, breast tumors, methylation, tumor suppressor gene, $Z A C$

\section{Introduction}

A recently isolated cDNA encoding a new zinc finger protein has been mapped to 6q24-q25, a known hot spot for genetic loss in breast cancer. The gene has been independently isolated by two groups, and has been named as LOT (lost on transformation) and ZAC (Zinc finger protein, involved in induction of Apoptosis and control of Cell cycle progression). This area of the genome shows frequent loss in breast carcinomas, and is likely to harbor several tumor suppressor genes; however, no candidate gene has yet been assigned to this region.

\section{Aims}

To investigate $Z A C$ expression in breast cancer cell lines and carcinomas.

\section{Comments}

The long arm of chromosome 6 shows frequent loss of genetic material in a range of solid tumors, including breast, although identification of the critical genes has thus far remained elusive. Given the antiproliferative properties and chromosomal location of $Z A C$ on $6 \mathrm{q}$, as well as the data presented here showing its downregulation in breast cancer cell lines and primary tumors, it would appear to be a strong candidate for a tumor suppressor gene. The expression data in the tumor samples are less compelling than that in the cell lines, however, and as the authors point out, confirmation using in situ hybridization and immunohistochemistry is required. Much work (in particular the proposed analysis of Zac1 knockout mice) also remains to be done to characterize the implications of $Z A C$ loss for breast cancer initiation and/or progression.

\section{Methods}


Eight breast cancer cell lines and a panel of unselected primary breast tumors were used in this study. Localization of $Z A C$ in normal tissues was carried out by in situhybridization. Single strand conformation polymorphism (SSCP) and sequencing were used for mutation detection. Expression analyses utilized northern blots, the RNase protection assay, and reverse transcriptase (RT)-PCR. Gene methylation was examined using 5-azacytidine (AzaC).

\section{Results}

In situ hybridization using an antisense $Z A C$ probe localized the protein in normal mammary ductal cells, though not in the stroma. The most luminal cells were the most strongly labeled. SSCP analysis revealed no mutations or polymorphisms in the $Z A C$ coding regions in a panel of 45 breast tumor samples which showed loss of heterozygosity (LOH) at the 6q23-q25 locus. This observation was confirmed by sequencing four tumor samples showing LOH with five markers in this region, as well as eight breast cancer cell lines. No ZAC mRNA was detected in five out of eight cell lines, and the remaining three showed reduced expression compared with that for normal breast tissue. Treating the cell lines with the methylation-interfering agent $\mathrm{AzaC}$ resulted in the expression of the $Z A C$ protein in three out of the five $Z A C$-negative cell lines. The other two remained negative. The three cell lines which were $Z A C$-positive under control conditions displayed enhanced $Z A C$ expression after AzaC treatment. $Z A C$ expression in unselected primary breast tumors was highly variable, although it was notably reduced in several of the samples.

\section{Discussion}

$Z A C$ encodes a new zinc finger protein with antiproliferative properties, and is located on chromosome 6q24-q25 This is a region thought to harbor at least one tumor suppressor gene important in breast cancer progression. $Z A C$ is expressed in normal mammary tissue, and has been shown here to localize to the most luminal layer of the epithelial cells, from which the majority of breast tumors arise. $Z A C$ expression was lost from or downregulated in eight breast cancer cell lines as well as in several primary tumors compared with expression in normal mammary tissue. This loss of expression was at due at least in part to gene methylation, and not to homozygous deletion of the $Z A C$ coding region. All the evidence points to $Z A C$ being a good candidate for a tumor suppressor gene of potential importance in breast cancer progression. 


\section{References}

1. Bilanges B, Varrault A, Basyuk E, Rodriguez C, Mazumdar A, Pantaloni C, Bockaert J, Theillet C, Spengler D, Journot L: Loss of expression of the candidate tumor suppressor gene ZACin breast cancer cell lines and primary tumors. Oncogene. 1999, 18: 3979-3988. 